\title{
マスコンクリートの熱変形および熱応力に関する実験的研究
}

\section{AN EXPERIMENTAL STUDY ON THERMAL STRESS AND THERMAL DEFORMATION OF MASSIVE CONCRETE}

\author{
石川雅 美*·前田強司**・西岡哲***.田辺忠顕**** \\ By Masami ISHIKA WA, Tsuyoshi MAEDA, Tetsu NISHIOKA and Tada-aki TANABE
}

\begin{abstract}
The effect of external restraint is one of the most important factors in discussing the mechanism of the thermal stress in massive concrete. From the results of recent theoretical investigations, relative displacement in both horizontal and vertical direction is suggested to be occurring at a joint of restrained concrete and restraining body such as rock or soil or even old concrete cast sometime ago before the casting of new concrete. These phenomena, however, have not confirmed by experimentally. In this paper, it was shown that the results of the thermal stress experiment with large scale massive concrete specimens were made having two parts, the base and wall on it. Each specimen has the different rigidity at its joint. The thermal deformation of these specimens was observed with high sensitive displacement meter, and the above mentioned phenomena were confirmed. The relationship between thermal deformation and rigidity of a joint was discussed based on the results of this experiment.
\end{abstract}

Keywords : mass concrete, thermal stress, compensation line method

\section{1.はじめに}

マスコンクリートの温度応力発生に支配的影響を及ぼ す外部拘束の実体は, 有限要素法 (FEM) による温度 応力解析を通じてかなり明らかにされてきた.すなわち， 温度変化に伴うコンクリートの体積変化を拘束するとい う比較的漠然とした従来の考え方から, 打継面での相対 変位による水平方向拘束の低減や, 曲げ変形とそれに対 する鉛直方向の拘束などという, より具体的な外部拘束 のメカニズムが解析的な面から考えられるようになっ た1).しかしながら, 打継面の相対変位や曲げ変形といっ た現象は，解析的には示唆されていても実現象としてま だ実測されているわけではない.これまで行われた研究 は，実構造物において実測した応力，ひずみなどをもと にした実験的研究, あるいは, 各種解析法を用いた解析 的研究のどちらかであり，応力あるいはひずみに重点を 置いたものがほとんどであった。したがって，マスコン

* 正会員 工修 東急建設 (株) 技術研究所土木構造研究 室（广 213 川崎市宮前区宮崎 2-13-2）

** 正会員 東急建設 (株) 技術研究所土木構造研究室 (同上)

*** 正会員 東急建設（株）技術研究所土木構造研究室長 (同上)

***** 正会員 工博 名古屋大学教授 工学部土木工学科 （４４64 名古屋市千種区不老町）
クリート硬化時の熱変形を直接実測した例に関しては, ほとんど報告されていないのが現状である.

そこで著者らはコンクリート硬化時の熱変形に着目し た実験を行い，マスコンクリートの熱変形を直接計測す ることにした。この実験の目的とするところは，1）解 析的に示唆されている曲げ変形や, 打継面での相対変位 を実験的に確認し，2）観察されるコンクリートの変形 パターンと外部拘束作用の大きさとがどのような関係と なるのかを明らかにすること．3）また，コンクリート 内部の応力およびひずみ分布のパターンと変形とはどの ような関係があるかなど, 実際の変位現象を確認し，そ のうえで，ひずみ分布，応力分布を明らかにすることに ある. 温度応力実験におけるひずみは, 周知のように温 度ひずみ成分, 応力ひずみ成分, クリープひずみ成分の 和であり，いずれの成分の量を単独で計測しても，その 他の量が不確定であれば，その量も不確定となる.そこ で本実験では，ひずみの各成分量が不明確にならないよ うに，変位だけでなく，温度，応力，ひずみを測定し， それらのデータを互いに照合することによって，マスコ ンクリート硬化時の性状に対して多角的に観察した。

著者らはこの実験に関し，その第 1 報として, 実験の 概略および観察されたデータについて簡単な報告を行っ た . 本報では, 同実験の内容について, 詳しく述べる 
と同時に, コンペンセーションライン法 (C. L 法) を 用いて, 観察された変形についての理論づけ等を行い, 上記 3 点の実験目的に対し検討を加えたものである.

\section{2. マスコンクリート温度応力実験}

マスコンクリートの温度応力に及ぼす外部拘束の影響 の度合いは, 主に 3 つのパラメーター, 1) 拘束体の剛性, 2）打継面（あるいは拘束面）での付着性状，3）打設さ れたコンクリートの $L / H$ (長さ/高さ)，なよ゙によって 評価できると考えられる．著者らは，まず打継面の付着 性状に着目して, この性状の違いが温度応力挙動にごの ように影響するかを調べた，実験に用いた試験体は，図 一1に示すように拘束体（高さ $1.0 \mathrm{~m}$ ，幅 $0.95 \mathrm{~m}$ ，長さ $15.0 \mathrm{~m}$ ) と壁状の被拘束体（高さ $1.0 \mathrm{~m}$, 幅 $0.3 \mathrm{~m}$, 長 さ $15.0 \mathrm{~m})$ とから成る実構造物大の大型マスコンクリー 卜試験体である.

これまで行われた大型試験体を用いた温度応力実験で は，拘束体となるコンクリート部分が直接地盤に打設さ れていたため，被拘束体が拘束体から受ける外部拘束の 影響と，その他地盤などからの影響との区別が不明確で あった．外部拘束の作用を実験的に明らかにしようとす るのであれば，試験体全体の外部拘束に関する境界条件 を十分に明確にしておく必要がある，そこで，本実験で は拘束体底面に特殊なすべり機構を設け, 拘束体の水平 方向の変形をできるだけ許容するようにした．このすべ り機構は，図一2に示すように床コンクリート上にセル フレベリング材（SL 材）を打設し，その上にテフロン シート 2 枚と厚さ $0.3 \mathrm{~mm}$ の鉄板を敷いたものである. 本実験には, 試験体全体の拘束条件を明確にしたことの ほかに, 以下のような特徴がある.

1）応力, ひずみ, 変位をそれぞれ独立に，そして同 一の箇所で測定した．特に変位については，1/2000 $\mathrm{mm}$ の分解能をもつ高感度型の変位計を 70 台使用して, 温度上昇から降下に至るまでの試験体全体の変形を測定 した.

2）実験はプレハブの室内で行い，外気温などの環境

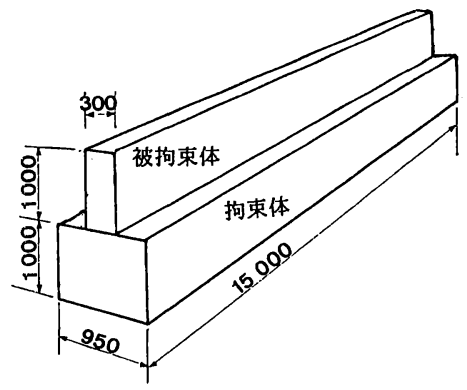

図一1大型マスコンクリート試験体
条件の変動を小さく押さえ，計測データの信頼性を高め た.

実験は，図一3に示すように，拘束体と被拘束体の間 の打継面の性状の異なる 3 体について実施した．以下， 打継面の性状の異なる各モデルを $\mathrm{M} \mathrm{1}, \mathrm{M} 2, \mathrm{M} 3$ とよ ぶ. 各モデルの特徵は次のとおりである.

1） M 1 : 拘束体上面をサイドブラスト処理した後, 入念に被拘束体（無筋）を打継いだ. 通常の無筋コンク リート構造物での打継ぎを最も入念に行った場合を想定 したモデルである．この場合に，打継面に相対変位が生 じるか否かを観察するため, せん断変位計と, 受感部に アンカーを設け, 引張側も測定可能なように, 独自に開 発したひずみ変換型圧力計を打継面内の 3 か所に設置し た.

2） M 2：拘束体と被拘束体の間に，SL 材，テフロ ンシートなどを用いた図一2 と同じすべり機構を設け た.したがって，被拘束体（無筋）は，自重作用の他は 拘束体から外部拘束なよ゙，ほとんど受けないと考えられ る. 被拘束体が比較的自由な変形をしたときの打継面の 圧力分布を測定するため, 打継面内の 11 か所に小型の 圧力センサー（圧縮域のみ測定可能）を設置した．実験 終了後試験体をジャッキで押し，このすべり機構の静止 摩擦係数を調べたところおよそ 0.1 であった。

3）Ｍ 3：打継面および被拘束体内に通常の壁式構造 物と同程度の配筋を施し，被拘束体に対する拘束体から の外部拘束を大きくしたもので，打継面の付着が最も大 きいモデルと位置づける. 打継面内の 3 か所に M 1 と 同じせん断変位計を設置した. M 3 では, 配筋が施して あるため, サンドブラスト処理は行わなかったが, 打継 ぎにあたっては,打継面にセメントペーストを塗布した.

このほか，拘束体を作製したときにも，その応力，お よび変形を計測しており, 後の議論では, 拘束体のみの 場合として M 0 とよぶことにする.

拘束体と, 3 つの被拘束体に使用したコンクリートは, 表一1 に示すように, 単位セメント量 $280 \mathrm{~kg} / \mathrm{m}^{3}$, 水七 メント比 $58.9 \%$, 呼び強度 $240 \mathrm{~kg} / \mathrm{m}^{3}$ の通常の土木構 造物に用いられる一般的な配合である. 実験を行ったプ レハブ室内において水中養生した円柱供試体の圧縮強 度，および弾性係数の，最小二乗法による近似式を図一

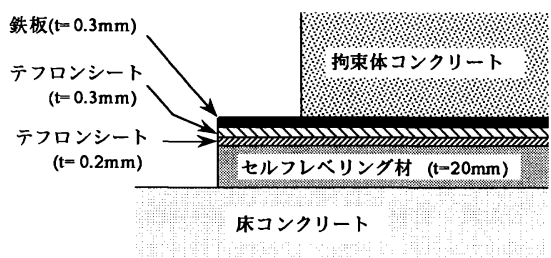

図一2 拘束体底面の特殊なすべり機構 

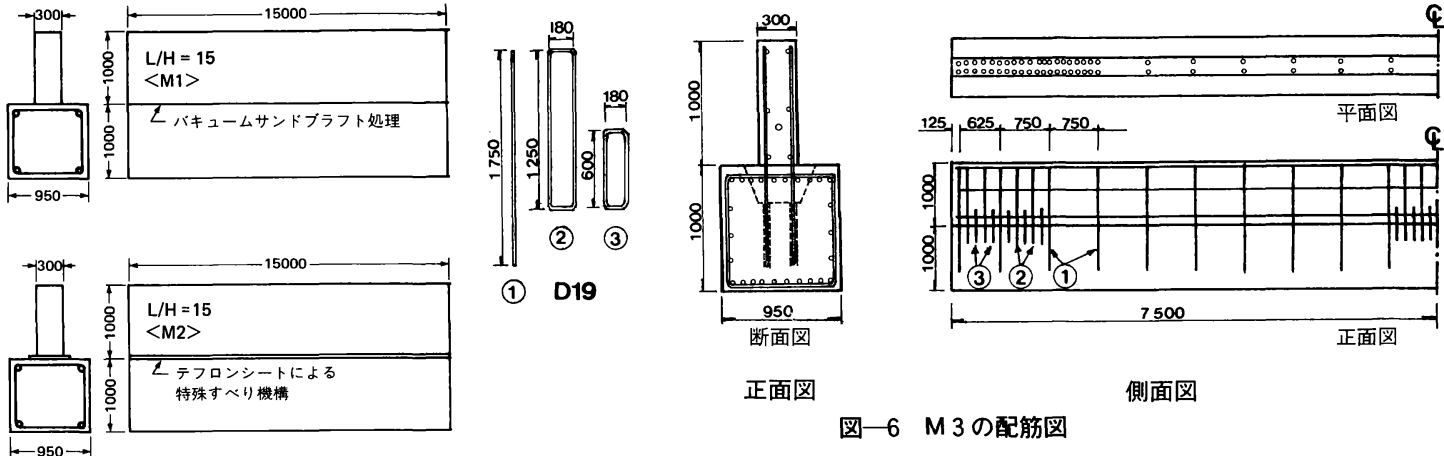

正面図

\section{図一 6 M 3 の配筋図}

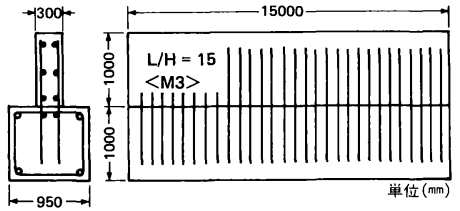

と同じすべり機構を作製し，その上に被拘束体 M 2 を, '86 年 11 月 18 日に作製した. M 2 の試験終了後, 被拘 束体と拘束体の上半分を撤去し，拘束体に鉄筋をたて込 み，配筋を施した．図一6にこのモデルの配筋を示す. '87 年 8 月 7 日に拘束体を修復した後, '87 年 9 月 2 日 に被拘束体 M 3 のコンクリートを打設した.

これら 3 つの試験体において, 拘束体の上面に被拘束 4, 5 に示す.

拘束体部分のコンクリートは, 1985 年 7 月 2 日に打 設した.この拘束体上に時期をずらして，M 1，M 2, M 3 の3つの被拘束体を作製した。被拘束体 M 1 は'85 年 8 月 21 日に作製し，実験を開始した。 M 1 の実験終 了後, 被拘束体部だけを取り壊し, 拘束体上面に図一2

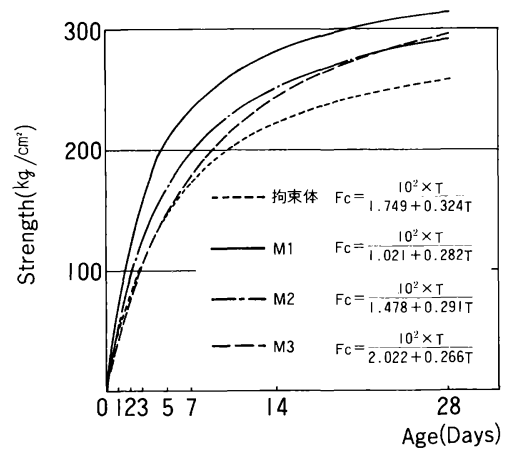

図一4 コンクリートの圧縮強度近似曲線

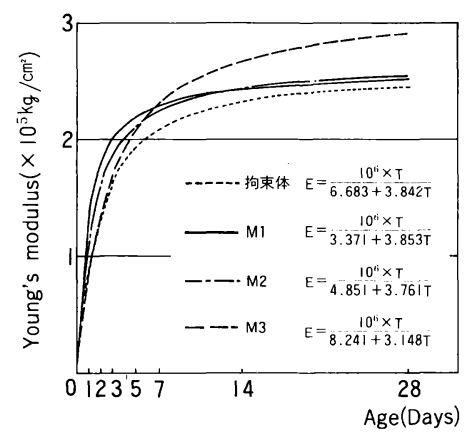

図一5 コンクリートの弾性係数近似曲線 温度, 応力, ひずみ，そして変位を計測した。各武験体 の計測項目を表一2 にまとめて示す. 図一7は, M 1 と M 3 および, M 2 の応力計, ひずみ計, せん断変位計な どの設置位置を示したものである.ただし，圧力計は， M 1 だけにセットされている. 計測断面は, 図一7に示 すように, A〜Eの 5 つである.

M 2 と M 3 では, M 1 と比べ, 変位計の不動ばりの たて込み位置の関係で設置位置が多少異なる.M 1 では, 不動ばりは床コンクリート中に定着してあるが，M 2 ， M 3 では, 床コンクリートの下 $1 \mathrm{~m}$ まで掘り下げ，こ こにコンクリートブロックとともに定着させた. そして， 㦿コンクリートと，このコンクリートブロックとの境界 には，発泡スチロールを入れて互いの干渉をなくし，不 動点としての信頼性を高めた. また, 不動ばりの温度を 測定しておき, 室温の変化による不動ばりの温度変形量 を算出した. 不動ばりの温度変形は, 水平方向の変位に 対しては, 無視し得るほど小さいため補正は行わなかっ たが, 鉛直方向では, コンクリートの鉛直変位の最大值 の 2 割程度であったので，これを補正した。

M 1, M 2 と M 3 の変位の測定位置を図-8 に示す. これらの図で, 被拘束体最上部の変位計と, $\mathrm{A}$ および $\mathrm{E}$ 断面以外の変位計は鉛直と水平を一組として, 表側 と裏側にそれぞれ一組ずつセットしてある.計測間隔は, 30 分から 2 時間である.また，本実験はプレハブ室内 で行ったため環境の大きな変動はない. 試験体の温度上 昇量を大きくするため, 拘束体の側面に $5 \mathrm{~cm}$, 被拘束 体側面に $10 \mathrm{~cm}$ の断熱材 (発泡スチロール) を貼付けた. 被拘束体上面は, 乾燥を防ぐため, 被拘束体上面の温度 
と同じ温度で湛水養生とした。

\section{3. 実測されたマスコンクリートの熱変形性状}

図一9は, M 0 (拘束体のみ), M 1, M 2, M 3 の試 験体の温度上昇過程から降下に至るまでの試験体全体の 変形を 70 台の高感度型の変位計 (分解能 $1 / 2000 \mathrm{~mm}$ ) を用いて測定した変形図である。この図からまず明らか なことは, 解析的にのみ指摘されていた曲げ変形が，拘 束体のみの試験体（M0）も含めて，いずれの試験体に ついても実測され，その存在が初めて確認されたことで ある. また，いずれの試験体においても打継面に水平方 向のすべりが生じていることが明らかとなった.

最初に最も単純な拘束体の変形について述べると, 温 度がピークに達する材令 1 日において，全体として下に 凸な曲げと水平方向の伸びを生じ，端部の鉛直上昇変位 は, $\mathrm{A}$ 側の平均と $\mathrm{E}$ 側の平均で, それぞれ, $0.265 \mathrm{~mm}$, $0.186 \mathrm{~mm}$ ，同様に水平変位は， $\mathrm{A}$ 側で $1.010 \mathrm{~mm}, \mathrm{E}$ 側 で $0.700 \mathrm{~mm}$ となるのが認められた. その後, 材令の経 過とともに, 収縮に転じ,材令 10 日の時点では反転して, 上に凸の曲げ変形と, 水平方向は初期状態を超えて収縮 となり，それぞれ， $\mathrm{A}$ 側 $-0.130 \mathrm{~mm}, \mathrm{E}$ 側 -0.089 $\mathrm{mm}$ の鉛直変位, $\mathrm{A}$ 側 $-0.535 \mathrm{~mm}, \mathrm{E}$ 側 $-0.684 \mathrm{~mm}$

\section{表一1 コンクリートの配合}

\begin{tabular}{|c|c|c|c|c|c|c|c|c|c|}
\hline \multirow{2}{*}{ 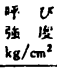 } & \multirow{2}{*}{$\begin{array}{l}x \bar{x} \\
=7 \\
\text { (cm) }\end{array}$} & \multirow{2}{*}{$\begin{array}{l}W / C \\
(\%)\end{array}$} & \multirow{2}{*}{$\begin{array}{l}S / a \\
(\%)\end{array}$} & \multirow{2}{*}{ 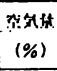 } & \multicolumn{4}{|c|}{ 他 } & \multirow{2}{*}{$\begin{array}{c}\text { 洪和枟 } \\
\text { Poo. } \\
\text { No.70 } \\
\end{array}$} \\
\hline & & & & & C & $w$ & $\mathbf{S}$ & G & \\
\hline 240 & 9 & 58 & $a^{4}=$ & $4 \pm 1$ & 280 & 105 & & 948 & 2.80 \\
\hline
\end{tabular}

C : H通ホルトタンドセメン

\section{表一2 計測項目}

\begin{tabular}{|c|c|c|c|c|}
\hline 计 训 項目 & 偖器 & M 1 & M2 & M 3 \\
\hline 温 设 & C C䓡電対 & $45(41)$ & $34(42)$ & $34(42)$ \\
\hline LE & 直効応力計 & B( 4) & $6(4)$ & $6(4)$ \\
\hline ひする み & 埋钤型程計 & $9(4)$ & $9(4)$ & $9(4)$ \\
\hline 热䀝根保数 & 無応 力䀯 & i( 1$)$ & $I(1)$ & I( 1$)$ \\
\hline 相 対 变位 & t泚变位䑒 & 3 & 0 & 3 \\
\hline 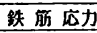 & 些ゲーシ & \begin{tabular}{|l|}
0 \\
\end{tabular} & 0 & 27 \\
\hline 娓 位 & 変 位 璟 & $42(24)$ & $34(36)$ & $34(36)$ \\
\hline 正 & 王 力 融 & 3 & $0(11)$ & 0 \\
\hline
\end{tabular}

数字は被拘束体の部测点数

\section{表一3＼cjkstart変位量のまとめ}

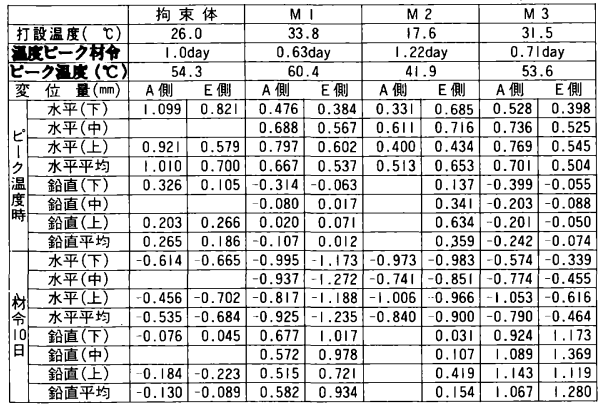

の水平変位を生じる結果となった．ここで，水平方向の 変位については，打設終了直後の位置より膨張側をプラ ス，収縮側をマイナスとした。また，鉛直方向について は，打設終了直後の位置より上側をプラス，下側をマイ ナスとした。

拘束体との接着面にテフロンシートのある M 2 では, 被拘束体の左右の変形が非対象になっている.これは, $\mathrm{A}$ 側の鉛直方向の変位計にトラブルがあり,この位置 の変位を正確に测定できなかったためである．拘束体 （M 0) は，M 2 と同様な拘束条件をもち，後で述べる が，温度分布から決まる自由変形の形状も同様である. $\mathrm{M} 2$ の $\mathrm{E}$ 側は, 拘束体之同様の変形形状となっている. したがって, M 2 の A 側も $\mathrm{E}$ 側と同様な変形をしてい るものと推測されるが, M 2 についての以下の議論は,

$\mathrm{E}$ 側の変形について行うものとする. $\mathrm{E}$ 側のピーク温 度時の水平変位は $0.537 \mathrm{~mm}$, 上方への鉛直変位は $0.359 \mathrm{~mm}$ であり, 材令 10 日の水平変位は $-0.900 \mathrm{~mm}$ であった．M0の材令 10 日の鉛直変位は，初期の位置 より下側であったが，M 2 は，初期の位置より上側の +0.154 mm であった. M 1, M 3 の試験体では, M 0, M 2 とは逆に温度上昇時に端部が下方に変位しながら膨 張し，上に凸の形になった，温度降下時には，端部は逆 に上にそり上がりながら収縮する，いわゆる下に凸の形 になる挙動が観察された。これら試験体の詳細な変位量 については表一3を参照されたい。

さて次に，実測変形の理論的な説明づけ，あるいは妥

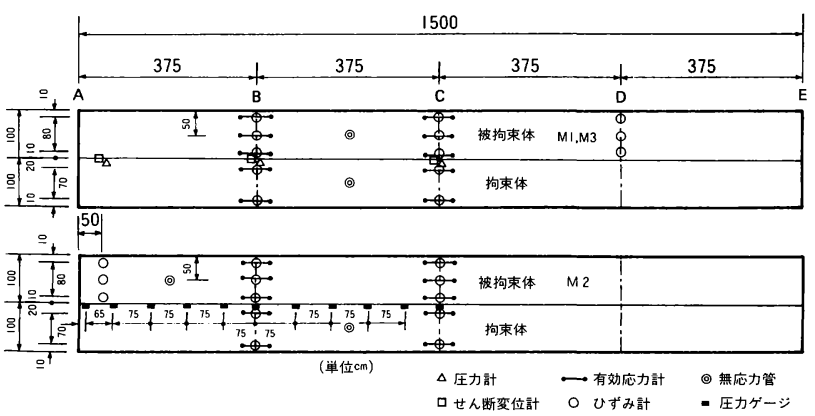

図一7 有効応力計，ひずみ計などの埋設位置

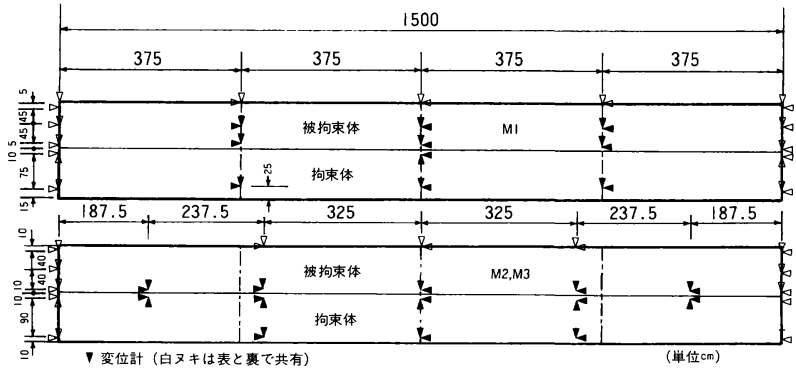

図一8 变位の測定位置 
拘束体 (MO)
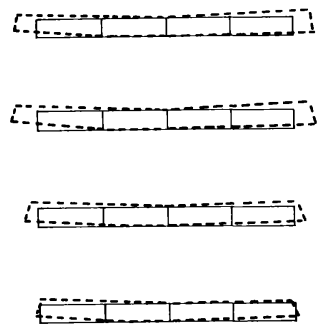

[C]

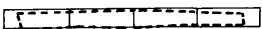

$\mathrm{M}$
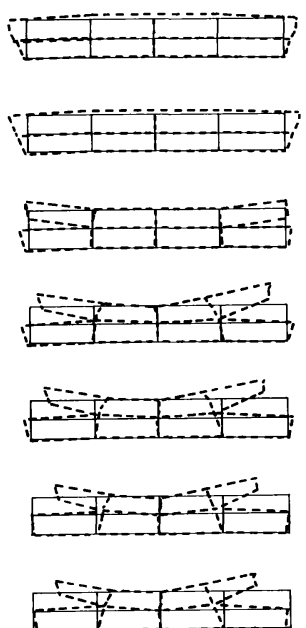

M2

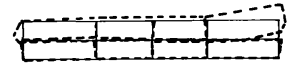

1day

2day

3day

5 day

10day
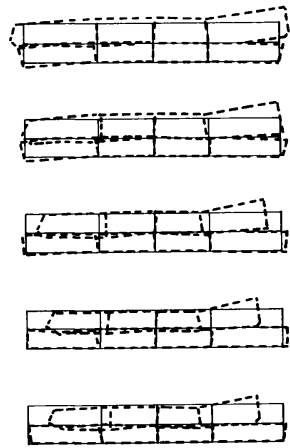

14 day
M3
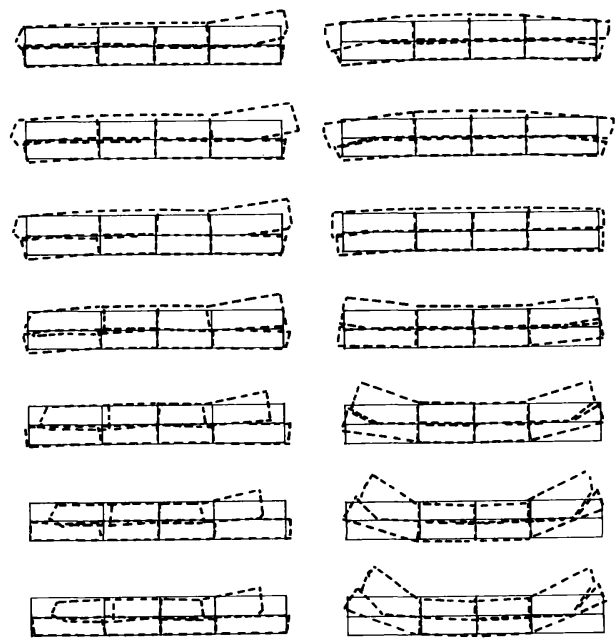

図一9＼cjkstart各試験体の変形図

当性の検討が必要となる. 詳細な数值モデルにより，ク ラック面, あるいは剝離面における応力伝達, 時間依存 性の若材令コンクリートの物性の変化などにより行う検 討は別報に襄り，ここでは大局的に理解を可能にする C. L 法，あるいは C. P 法的観点から以下の考察を行っ てみた，図一10 (1) (3)は，被拘束体の中央断面で計測 された温度を示したものであるが，この温度に対して，

C. L 法を用いて自由な熱変形の曲率 $\phi$ と軸方向平均ひ ずみ成分 $\varepsilon$ を時系列として求めると，図一11，12 のよ うになる.これらの図で, 右側の縦軸の数字はそれぞれ， 曲率に対応する試験体端部の鉛直変位量と, 平均自由膨 張ひずみに対応する水平変位量である，すなわち，これ らは試験体が, 無重力状態で自由な熱変形を受けるとき, 端部が記録する鉛直変位と水平変位を表わしていると考 えられる．M 2 についてこれをみると，材令 4 日ないし 5 日頃までは, 直線的に負の曲率（下に凸）が増大し, 材令 2 日ぐらいでは $\phi=-4 \times 10^{-7} / \mathrm{cm}$ (端部の浮き上

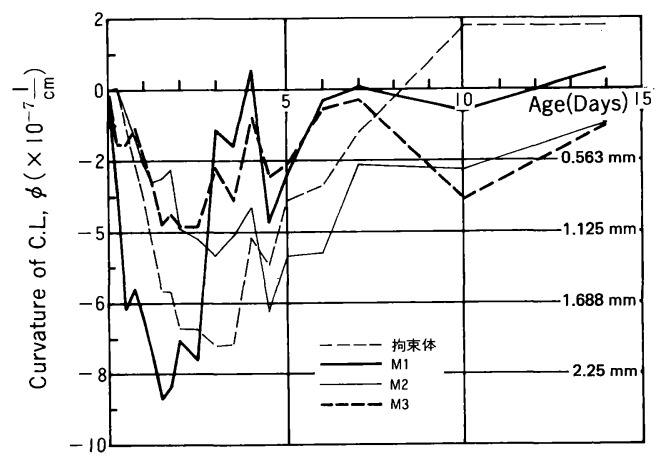

図一11 曲率 $\phi$ の傾きの履歴
がり変位量 $1.125 \mathrm{~mm}$ ) となっている，実際には，図一 9 に示したように下に凸ではあるが，端部の浮き上がり 量は $0.26 \mathrm{~mm}$ 程度と, 自由熱変形の $1 / 4$ 程度となって いる.これは，当然のことながら，自重による拘束効果 のためであろう．材令 5 日以降は, 自由変形の曲率は, 徐々に減少し, 材令 2 週程度では, $(-1) \times 10^{-7} / \mathrm{m}$ にま で減少するようであるが, 実測では, 平均の浮き上がり 量はほぼゼロとなっている，平均自由膨張ひずみから計 算される水平方向の変位量は, 材令 1.5 日で最大 $2 \mathrm{~mm}$, 材令 2 週でー0.9 mm となっているが実測ではそれぞ れ， $0.5 \mathrm{~mm}$ と $-0.9 \mathrm{~mm}$ であった.すなわち，実測の 平均水平変位量は, ひずみから計算される值に対して膨 張域で $1 / 4$ 程度, 引張域ではほぼ同様な值であった。こ れらの差は自重作用，あるいは水平方向のテフロンシー トの摩擦による外部拘束の影響と考えられる.

さて, M 0, M 2 と全く逆の変形となった $\mathrm{M} 1$ および $\mathrm{M} 3$ の変形も基本的には, M 0, M 2 と同様の自由変形

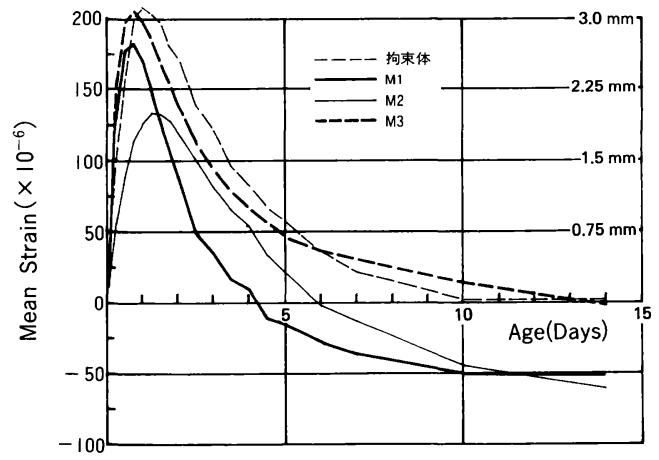

図一12 軸方向ひずみ履歴 

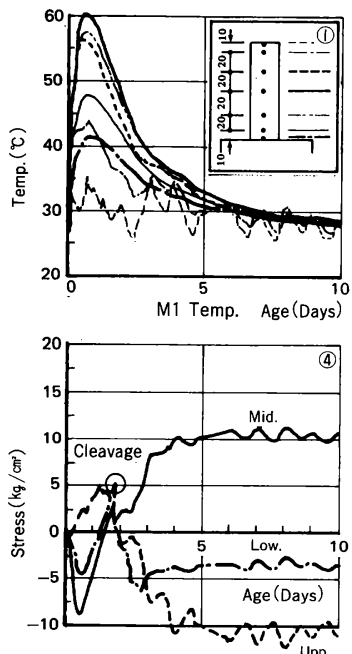

M1 Stress (B-section)

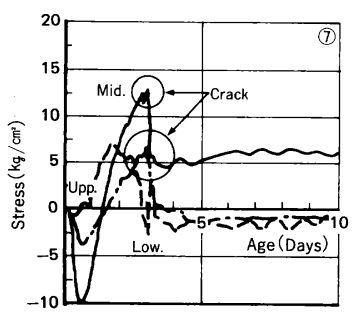

M1 Stress (C-section)

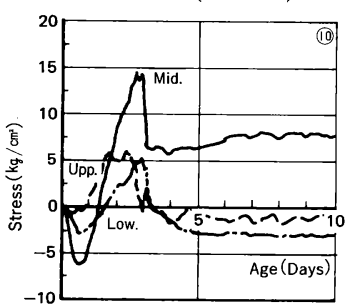

M1 Strain $\rightarrow$ Stress

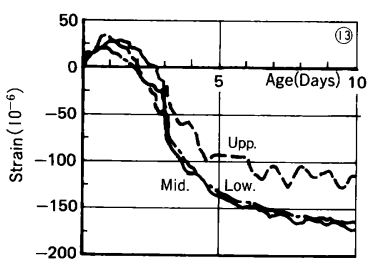

M1 Strain

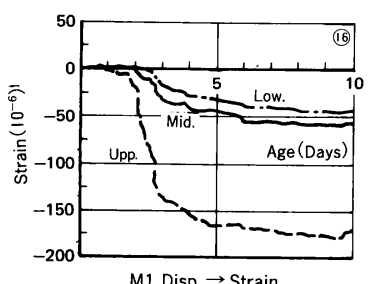

M1 Disp. $\rightarrow$ Strain
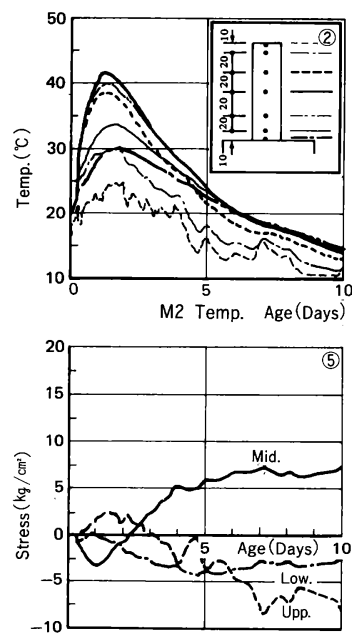

M2 Stress (B-section)

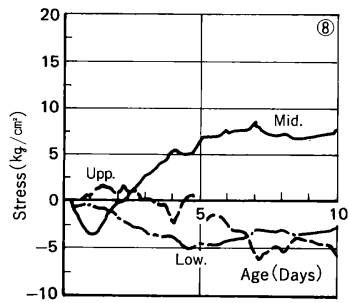

M2 Stress (C-section)

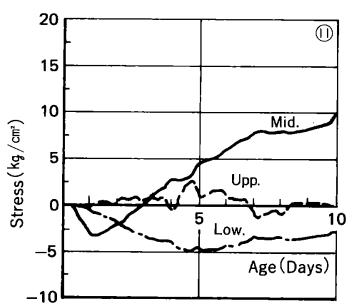

M2 Strain $\rightarrow$ Stress

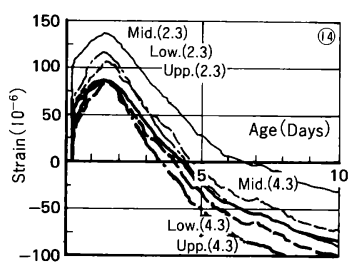

M2 Strain

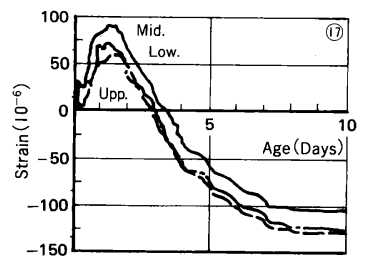

M2 Disp. $\rightarrow$ Strain
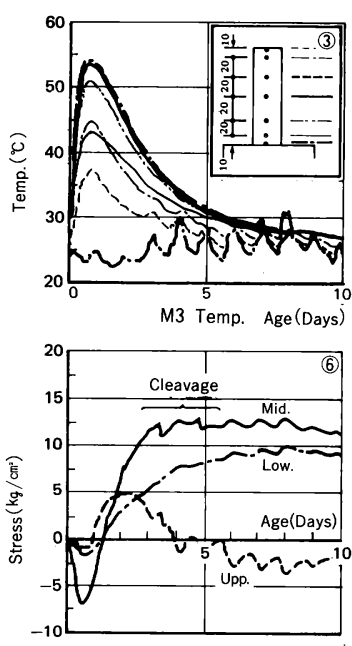

M3 Stress (B-section)

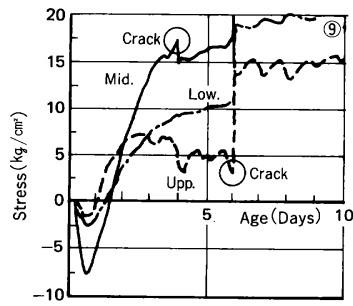

M3 Stress (C-section)

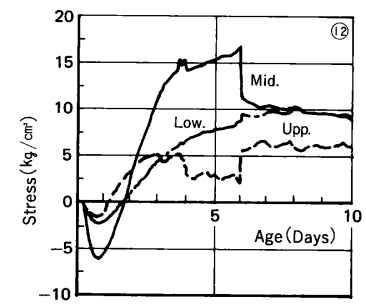

M3 Strain $\rightarrow$ Stress

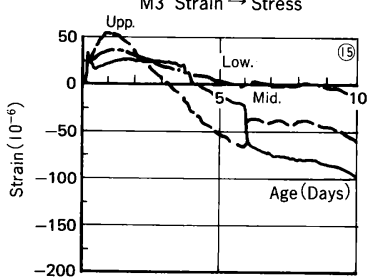

M3 Strain

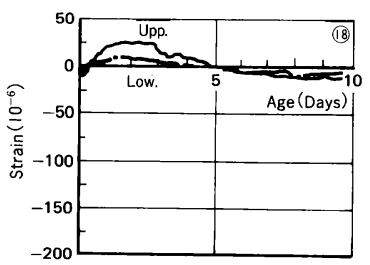

M3 Disp. $\rightarrow$ Strain

Low:Lower Layer, Mid:Middle Layer, Upp:Upper Layer, Compression(+), Expansion(+), Tension(-), Contraction(-) 


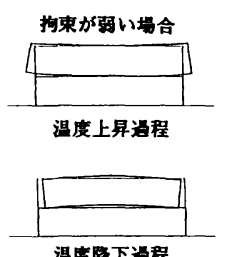

温度隆下识程

図-13

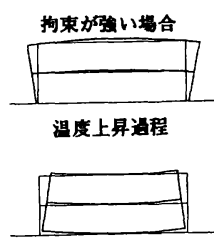

榅度居下道程

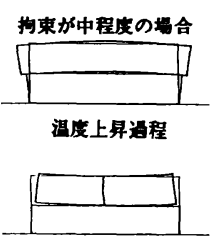

温度相下的
各試験体の変形形状のモデル化

を起こそうとする上部コンクリートを拘束体が拘束する 程度に応じて, 変形レスポンスをすると考えることによ り，説明することが可能と思われた．すなわち，図一11 の $\phi$ の傾きから, M 1 は材令 2 日から, M 3 は材令 2.5 日から，それまでの下に凸の傾向を強める状態から反転 し，上に凸の状態に向かう．材令 2 週で，M 1 はわずか に上に凸となるが，M 3 は上に凸の状態まで至らない． CL 法による以上の自由変形の推定に対し, 実測の結果 によれば，温度上昇時に上に凸の形となり，温度降下時 には，逆に端部がそり上がる下に凸の形になった．M1 では，材令 1.5 日，M 3 では，材令 3 日に上に凸から下 に凸の状態になる。したがって，M 1 とＭ３変形は， 自由変形とは明らかに全く逆の変形パターンになったの である.

これまでの実験結果の考察から, 被拘束体の変形のパ

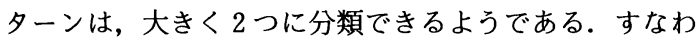
ち，1）自由な変形形状とは全く逆の変形形状を示す, 打継面にある程度以上の拘束がある場合の M $1, M 3$ 型 と，2）自由変形形状がほぼ保存される，打継面にほと んど拘束がない場合の M 2 型である.これら 3 つの被 拘束体の変形挙動は, 温度上昇時之温度降下時でそれぞ れ図一13 のようにモデル化できるようである。一般に， コンクリートが外部拘束を全く受けずに自由な熱変形を する場合には，その温度分布によって図一14のような 2 通りの変形形状となると考えられる.すなわち, 温度 の高い部分が，断面の形状と剛性から計算される重心よ りも, 下側にあるか上側にあるかによって, 変形が上に 凸になるか，下に凸になるかが決定される．もちろん， そのどちらでもない中立な場合もあるが，実際のマスコ ンクリートにおいては，まれであろう.

実測結果から推測すると，このような自由な変形は， 拘束面の拘束の度合いによって全く異なった見掛けの変 形形状に容易に変化し得るようである.このような現象
は, 解析的にもシミュレートされている，著者らは， FEM を用いて本試験体のパラメトリックスタディを 行った ${ }^{3)}$ が, その場合でも, 拘束面の拘束係数の微妙な 違いだけで, 異なる変形形状が得られた. 以上要するに, コンクリートが見掛け上どのような変形形状となるか は, 温度分布から決定される自由変形の形状とそれに作 用する外部拘束によって決定されることが実験的にも明 らかになったのである.

\section{4. マスコンクリートにおけるひずみ分布}

\section{（1）ひずみ計の改良}

前述した変形性状は直ちにひずみ分布に反映されるの であるが,生じているひずみ分布は, 応力の算定にあたっ て, 特に重要な要因であり, 応力計が開発される以前は, このひずみ值が計測し得る唯一の量でもあった．著者ら は, 拘束体作製時において, 観察されたひずみ値と有効 応力計との比較から, ひずみ值の精度に疑問を抱いた. すなわち, 埋設型コンクリートひずみ計のコンクリート 内での定着性が不十分な場合もあり得ると考えた。 そこ で，図一15に示すように，これまで用いていたひずみ 計のフランジ部にねじ型の金具を取り付け，その定着性 を高めるような改良を加えた。 その結果，十分とはいえ ないまでも以前に比べれば良好と思われる計測結果を得 ることができた，そこで，ひずみ計の改良についてまず 述べることにする。

図一16 は, 本実験で用いたマスコンクリート大型試 験体とは別の, 高さ $1.0 \mathrm{~m}$, 幅 $0.3 \mathrm{~m}$, 長さ $5.0 \mathrm{~m}$ のコ ンクリートブロック硬化時に, その中央断面に埋設した 2 種類のひずみ計の応力換算值と有効応力計の值を比較 したものである. 改良型のひずみ計は標準型に比へ，圧 縮域においても引張域においても有効応力計と良好な対 応を示した.ここでは示さないが, 同ブロックにセット した, 変位計から求めたひずみとの比較においても, 改 良型は良好な対応を示した。なお，ひずみから応力への 変換には，次式を用いた。

$$
\sigma(t)=\sum \varepsilon(t) E(t) \phi
$$

ここで, $\sigma(t)$ は材令 $t$ における応力, $\varepsilon(t)$ は材令 $t$ における応力成分ひずみの増分, $E(t)$ は材令 $t$ の弾 性係数，そして，申はクリープなどを考慮した弾性係数 に対する低減係数である. 図一17 は, 同じコンクリー トブロックの上層部, 中層部, 下層部の 3 か所に埋設し

\section{温度の高い部分が下にある場合}

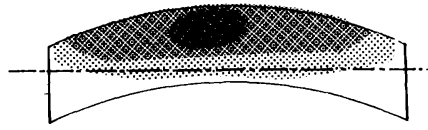

中立軘

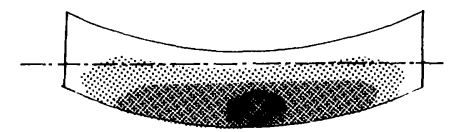

図一14 マスコンクリートの自由な熱変形形状 
た 2 種類のひずみ計からコンクリート断面内のひずみ分 布を求めたものである，標準型のひずみ計では，ひずみ が直線分布しているとはいいがたいが, 改良型のものは, ひずみの直線性がほぼ成立しているといえるであろう.

著者らは,これらのデー夕をもとに,温度応力実験を行っ ていく過程で，標準型のひずみ計から改良型のものへ切 り替えていった，M1は，拘束体，被拘束体ともにすべ て標準型，M 2 は，拘束体が標準型で，被拘束体が改良 型，M 3 は，拘束体の下側が標準型でそれ以外は改良型 である。

\section{（2）マスコンクリートにおけるひずみ分布}

図一10 (13)～(15)に各被拘束体の埋設したひずみ計から 得られた変形成分ひずみを示す.ひずみ計の初期值は, M 1 と M 3 では, コンクリート打設終了後 2.0 時間, $\mathrm{M} 2$ については, 2.3 時間（図一10 117)中のッコ内に 2.3 と記してある曲線）とした. M 1 と M 3 では, 最大 膨張ひずみの值は，M 2 に比べ小さくなっている．これ は, 拘束効果が大きいので, 当然の結果といえる．変位 計から求めたひずみ（図一10 (16)，(11)，(18) では，M 1, M 3 のスパン中央のひずみは, ほとんどゼロの值を示し, 材令の增加とともに収縮ひずみが増加している．一方 M 2 では，初期に急激に膨張ひずみが一見生じているよ うにみえる. 図一10 171は，M 2 の被拘束体両端部の変 形量を試験体長で割ってひずみを求めたものであるが, これによれば, 初期の急激な膨張はなく, その最大膨張 ひずみ量も $80 \times 10^{-6}$ 程度と小さい，そこで，初期值を， 打設終了後 4.3 時間として整理すると（図一10 170中の カッコ内に 4.3 と記してある曲線）変位から求めたひず

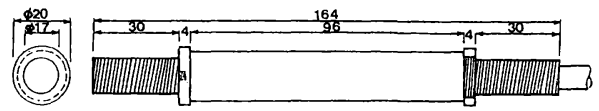

図一15 改良型ひずみ計

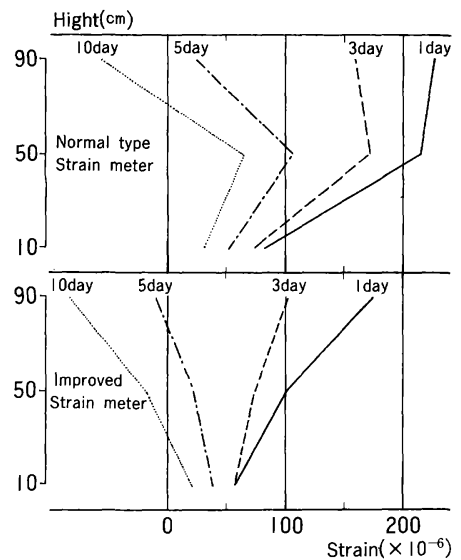

図一17 断面内のひずみ分布の比㜞

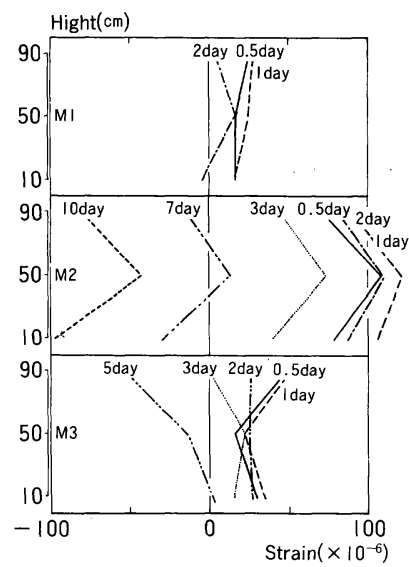

図一18 M1, M2, M3のひずみ分布
みと終始一致する傾向が得られた．変位計から，求めた ひずみはかなり安定しているのに対して，ひずみ計の值 は多少変動している，ひずみ計のとらえるひずみは，局 所的であり，かつコンクリートとひずみ計の剛性の比な ども関係してくるため，変動幅が大きいようである．い ずれにしても，初期材令では，従来ひずみ計で測定されて いた值は，実際よりも大きめの值を与えていたというこ とが，この変位による測定值からもいえそうに思われる。

図一10 (10)（12)は，ひずみ計から応力を算出したもの であるが, 各被拘束体の有効応力計の計測結果と非常に よく対応している．また，図一18は，被拘束体の断面 内のひずみ分布を示したものである.クラック発生以降 は，ここには示していない，M 1，M 3 では，ひずみの 直線性がほぼ成り立っているといえるような良好な結果 であったが，M 2 では，中層部のひずみが大きく卓越し ている.ひずみの直線性については，材令 1 日を基底に とって整理すると，これらの試験体では，ほぼ成立して いるといえよう．材令 1 日以前については，さらに検討 が必要と思われる.

\section{5. クラック，剝離，および応力分布について}

M 1， M 2, M 3 の C 断面および B 断面における応 力測定値の経時変化を，図一10 (4)〜 (9)に示した。

図一10 (4)によれば M 1 試験体では，材令 1.5 日のと き， $\mathrm{B}$ 断面上層部と中層部の応力に急激な低下がみら

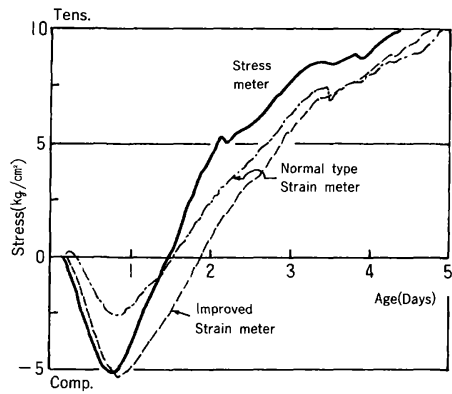

図一16 ひずみ計と有効応力計の比較

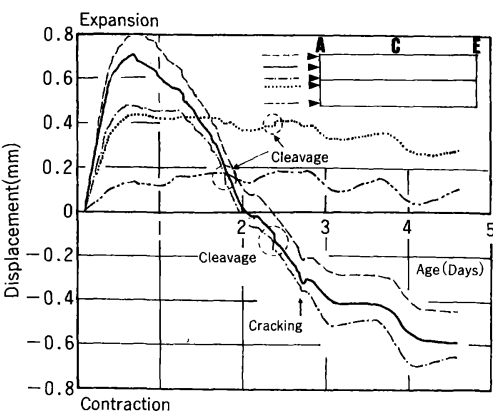

図一19 M 1 A 側の变位履歴 


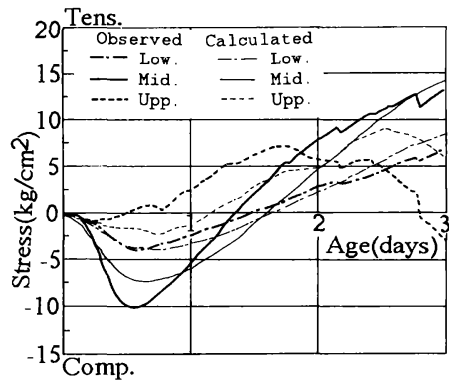

図一20 M 1 の解析と実測応力の比較

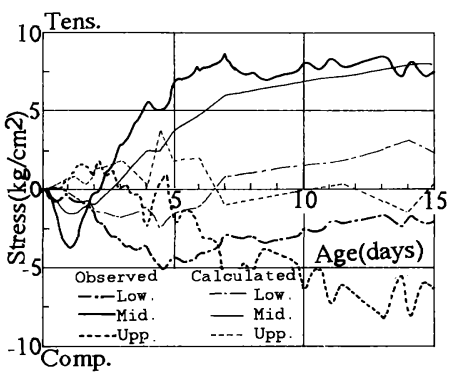

図一21 M 2 の解析と実測応力の比較

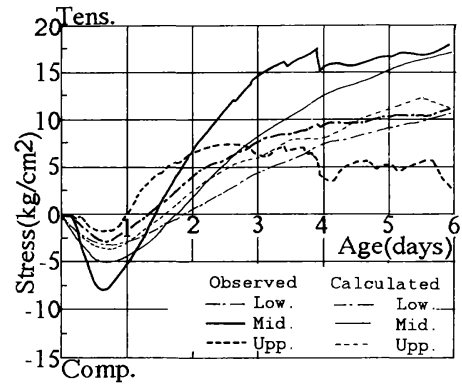

図一22 M 3 の解析と実測応力の比較
れた。これは，打継面の剝離による影響である．材令 2.5 日にも $\mathrm{B}$ 断面の応力に変動が起こっており, 剝離 がさらに進行したものと思われる．この現象は，A 側 で測定した水平方向の変位の経時変化にも現われてい る. 図一19にその部分を示す。材令 2.5 日では, 剝離 によって, 被拘束体下層部は縮み，拘束体上層部は伸び ている. 従来のマスコンクリートに関する研究では, 水 平方向にのみ注意が払われており, 剝離について言及し た論文はほとんど見当たらない.このような剝離による 応力開放は, 曲げ変形, あるいは鉛直変形の存在が温度 変形の中に確認されていれば，当然予想されたことで あった。C 断面では, 材令 3 日に, 上層部之中層部の 応力に急激な低下がみられたが，これはこの付近に生じ たクラックの影響であると考えられる.材令 5 日以降は, B， C 両断面ともに応力は平衡状態となった. 試験終了 後目視により観察したところ, 両端部とも試験体長さの 1/4 程度まで剝離が進行していること, また鉛直方向ク ラックは C 断面より $\mathrm{A}$ 側に $12 \mathrm{~cm}$ のところで発生して いることを確認した。

M 2 の応力履歴の B 断面を図一10 (4)に，C 断面を(8) に示す，M 2 では，B，C両断面ともほぼ同様の応力履 歴を示した. 両断面の中層部は, 材令 1.2 日の温度ピー クとともに，最大圧縮応力となり，これ以降引張側へ向 かい材令 6 日頃から平衡状態となった. 上層部の当初か らのゆっくりとした圧縮応力増加傾向は，材令 5 日頃か ら平衡状態になった，下層部では，材令 2 日頃を変曲点 として, 引張応力増加傾向から圧縮側へと推移した.

M 3 のC 断面では，材令 4 日付近に中層部に発生し たクラックは，材令 6 日に上下へ発展し，断面を貫通し た.このとき有効応力計の值が急激に引張側へ移行して いるのは, クラックが有効応力計をまたいで発生したた めである，C断面では，このクラック以降各部の応力 はほぼ平衡化した，B断面の応力を観察すると，材令 3.5 日に剝離による応力変動が起こっている.

ここで, 観察された応力に対する詳細な理論解析は別 報に譲り, 前と同様の理由から, C. L 法的観点から応
力值の検討を行ってみる.この場合に, クラックあるい は剝離の影響の少ない範囲が検討の範囲であることはい うまでもない，図一20〜22 は，実測された M 1，M 2， M 3 の被拘束体 C 断面の応力と, C. L 法による応力解 析の結果を比較したものである．C.L 法では，被拘束 体のみを計算対象としている，M 2 のような場合は，拘 束の状態が特種であり, 外部拘束係数を定める際, 日本 コンクリート工学協会 (JCI) の提案する図表 ${ }^{1)}$ を参照 することができないので，これまでの経験から， $R_{N}=$ $0.2, R_{M 1}=1.3, R_{M 2}=1.8$ と仮定した. この解析の結果 は, M 1, M 3 と比較して, 実测と良好な対応を示した とはいえない. 特に, 材令 3 日ぐらいまでの中層部の解 析応力は，実測と比べてもかなり小さい．このように， 底面での拘束が小さく，かつコンクリートの厚さが薄い 場合には，C.L 法は，実測と合いにくい要因があるよ うに思われる.

M 1 と M 3 の外部拘束係数は, JCI の提案する表か ら求め, $R_{N}=1.0, R_{M 1}=1.02, R_{M 2}=1.05$ とした. $\mathrm{M} 1$ と M 3 は, 形状および, 拘束体と被拘束体の剛性比が 同様であるため，C. L 法に用いる外部拘束係数の值は 等しくなる.この解析の結果は，実測值と良好な対応を 示しているが, より一層一致させようと思えば, 各材令 ごとに $R_{N}, R_{M}$ を変化させる必要がある．先にも述べた ように, M 1 と M 3 は, 打継面での挙動や, 応力の発 生傾向が異なっているが， $R_{N}, R_{M}$ を一定 (constant) とおいた C. L 法を適応しても，それほど問題でないよ うである.

次に，これらの忘力分布をクラス分けしてみる．著者 らは，一方向に大きな寸法を有するコンクリートに対し て，マスコンクリートの温度応力とひずみの発生パター ンを大きく 2 つに分類した ${ }^{2)}$. すなわち，外部拘束が卓 越する場合の A 型と, 打継面の鉛直方向の付着がわず かで水平方向の拘束が比較的少ない場合の B 型である. これら 3 つの試験体を, C 断面で観察された応力から, この分類に当てはめると, M 2 は曲型的な $\mathrm{B}$ 型で, $\mathrm{M}$ 3 は典型的な $\mathrm{A}$ 型となっている. M 1 は，これらの中 


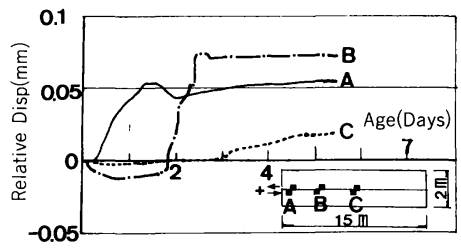

図一23 M1 の打継面の相対変位

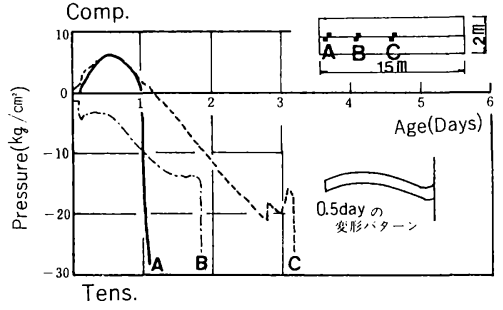

図一24Ｍ1の打継面の圧力履歴

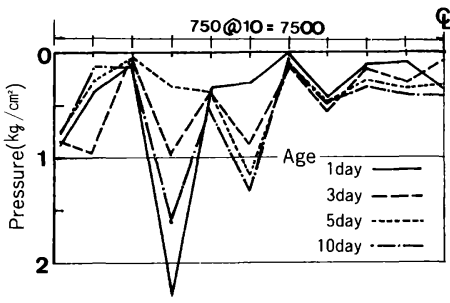

図一25 M 2 の打継面の圧力分布履歴
間的な傾向と認められるが，比較的 M 3 に近く，どち らかといえば $\mathrm{A}$ 型であろう。このような $\mathrm{A}$ 型，あるい は B 型の応カパターンに対応するマスコンクリートの 変形のパターンは, 先に示した 2 つの変形パターンとな るようである.

\section{6. 打継部の挙動}

図一23 は，M 1 の打継部の相対変位である.この図 から判断すると, 被拘束体は拘束体に対して, A 断面 では外側に，B断面では内側に変位している．C断面 ではほとんど変位していない。この現象は一見不可解な ようであるが，図一24 の圧力計の值とあわせて，この 部分の挙動を考えると次のようになるであろう。すなわ ち, 圧力計の值は材令 1 日までは $\mathrm{A}$ と C が圧縮に, $\mathrm{B}$ が引張になっていることから，A と C を支点にして B が上方へ変位していると推測される. A 付近は支点と なりながらも外側へ変位し，B は逆に上に持ち上げら れることによって中心側へ変位しょうとしているようで ある.なお,これらの計器はクラックや剥離の発生によっ てそれ以降の計測値が発散している。図一25は，M 3 の打継部の相対変形を示したものである. M 1 と M 3 とでは, 相対変形量のオーダーが異なってはいるものの, 傾向としては，一致している. 図一26 は，M 2 の打継 面で圧力を計測した結果である．打継面の圧力は一様で はなく，長手方向にいくつかの山や谷がみられる。この 現象は, 解析によっても示されている31. したがって, 計測された打継面での圧力分布の不均一さは計器の誤差 によるものではなく，実際の現象である可能性が高い. これは, 被拘束体に作用する拘束曲げモーメントが長手 方向でプラスになったりマイナスになったりしているこ とを意味するものである．ここでは，断定はできないが 今後の詳細な検討が必要であろう。

\section{7. ま と め}

実構造物大の大型試験体を用いてマスコンクリートの 温度応力実験を行い，これまで解析的にのみ示唆されて いた硬化時の曲げ変形の存在や，それに伴う打継面での 剥離や相対変位といった現象を実験的に確認した。そし
て, 実験的に観察された 3 つのモデルの変形パターンと それに対する C.L 法を用いた検討から，マスコンク リートが硬化時に示す変形形状は，コンクリートの自由 な熱変形と，それに作用する外部拘束の大きさの度合い により決定されることを示した。ここでの実験のパラ メーターとして着目した打継部の付着性状は，外部拘束 を規定するうえでの 1 つのパラメーターであるが，付着 の状態により外部拘束の大小を考えた場合には，マスコ ンクリートの熱変形パターンは大きく 2 つに分類され る.すなわち，1）外部拘束が大きい場合，見掛けのコ ンクリートの熱変形は, 自由な熱変形のパターンとは異 なるようであり，2）外部拘束が小さい場合には，自由 な熱変形のパターンがほぼ保存されると考えられる。こ の 2 つの変形パターンは著者らが分類した $\mathrm{A}$ 型と $\mathrm{B}$ 型 の応力パターン2) とまさしく対応するものである．そし て, 外部拘束作用の大きさの度合いにより，応力と同様 にこれら 2 つ変形パターンの中間的なものも存在する ようである．また，変形の計測結果では被拘束体は全体 的に上に凸になったり下に凸になったりしているが，打 継面の挙動を観察するとこのような変形と同時に局所的 にもかなり複雑な動きをしているようである．しかし， これについては，さらに詳細な検討が必要であると考え ている.

\section{参 考 文 献}

1）日本コンクリート工学協会：マスコンクリートの温度応 力研究委員会報告書, 1985.11 .

2）田辺忠顕・原口 晃・石川雅美：マスコンクリートの温 度応力問題における岩盤あるいは旧コンクリートの外部 拘束効果：マスコンクリートの温度応力に関するコロキ ウム講演論文集, pp. 83〜 90, 1982.8.

3）今枝靖典 - 石川雅美 - 西岡 哲 - 田辺忠顕：温度応力に よるマスコンクリートのカ学的挙動, コンクリート工学 年次講演論文集 10-2, pp. 175 180, 1988.

4）石川雅美・前田強司・西岡 哲：コンクリート埋設型ひ ずみ計の改良について, 第 43 回土木学会年次学術講演概 要集 5, pp. 466 467, 1988. 10.

5）石川雅美・西岡 哲·前田強司 - 田辺忠顕：大型試験体 によるマスコンクリートの温度応力実験, 第 10 回コンク リート工学年次講演会論文集, 2, pp. 169 174, 1988.

(1988. 10.25 • 受付) 